\title{
Improving Science Learning Outcomes in Theme 5 Using Google Form Media for Class V Students
}

\section{Okviana Elly Candra}

SD Negeri 2 Nglobo

okvianajiken1@gmail.com

\section{Article History}

accepted 14/11/2020

approved $21 / 11 / 2020$

published 26/11/2020

\begin{abstract}
The purpose of this study was to improve student learning outcomes in Science Theme 5 Subtheme 3 regarding ecosystem balance. This research is a Classroom Action Research (CAR) which was conducted in 2 cycles. Each cycle consists of planning, implementing, observing, and reflecting. The subjects of this study were students of class V SD Negeri $2 \mathrm{Nglobo}$ in the 2020/2021 school year, totaling 20 students. Data collection techniques using observation and test techniques. The assessment instrument uses item - item and observation rubric assessment. Analysis of the data used in the study included comparative descriptive techniques, namely statistical techniques by comparing scores. The results showed that the use of google form media can improve student learning outcomes in Science Theme 5 Subtheme 3 regarding ecosystem balance. This is evidenced by the learning outcomes in Cycle I, namely 10 students out of 20 or $50 \%$ who have not completed, while 10 students out of 20 or $50 \%$ have completed. In cycle II, there were 3 out of 20 or $15 \%$ students who had not completed, while 17 out of 20 students or $85 \%$ of the 20 students who completed it had completed. This means that student learning outcomes increase from cycle I to cycle II. The conclusion of this study is the use of google form media can improve learning outcomes Science Theme 5 Sub-theme 3 about the balance of the ecosystem in class V SD Negeri 2 Nglobo students.
\end{abstract}

Keywords: learning outcomes, google form, students

\begin{abstract}
Abstrak
Tujuan penelitian ini adalah meningkatkan hasil belajar siswa pada IPA Tema 5 Subtema 3 tentang keseimbangan ekosistem. Penelitian ini merupakan Penelitian Tindakan Kelas (PTK) yang dilaksanakan dalam 2 siklus. Setiap siklus terdiri dari tahap perencanaan, pelaksanaan, observasi dan refleksi. Subjek penelitian ini adalah peserta didik kelas V SD Negeri 2 Nglobo tahun pelajaran 2020 / 2021 yang berjumlah 20 peserta didik. Teknik pengumpulan data dengan teknik observasi dan tes. Adapun instrument penilaiannya menggunakan butir - butir soal dan pengamatan rubrik penilaian. Analisa data yang digunakan dalam penelitian meliputi teknik deskriptif komparatif. Hasil penelitian bahwa Penggunaan media google form dapat meningkatkan hasil belajar peserta didik pada IPA Tema 5 Subtema 3 tentang keseimbangan ekosistem. Hal ini dibuktikan dari hasil belajar pada Siklus I yaitu siswa yang belum tuntas sebanyak 10 peserta didik dari 20 peserta didik atau $50 \%$, sedangkan siswa yang tuntas sebanyak 10 peserta didik dari 20 peserta didik atau 50\%. Pada siklus II, peserta didik yang belum tuntas sebanyak 3 peserta didik dari 20 atau $15 \%$, sedangkan peserta didik yang tuntas sebanyak 17 peserta didik dari 20 peserta didik atau $85 \%$. Ini artinya hasil belajar peserta didik meningkat dari siklus I ke siklus II. Kesimpulan dari penelitian ini adalah penggunaan media google form dapat meningkatkan hasil belajar IPA Tema 5 Subtema 3 tentang keseimbangan ekosistem pada peserta didik kelas V SD Negeri 2 Nglobo.
\end{abstract}

Kata kunci: hasil belajar, google form, siswa

Social, Humanities, and Education Studies (SHEs): Conference Series https://jurnal.uns.ac.id/shes

p-ISSN 2620-9284

e-ISSN 2620-9292

This work is licensed under a Creative Commons Attribution-ShareAlike 4.0 International License. 


\section{PENDAHULUAN}

Dalam masa pandemi covid-19 yang saat ini dialami oleh seluruh rakyat Indonesia memberikan dampak yang luar biasa pada berbagai bidang, tidak terkecuali bidang pendidikan. Adanya pembatasan sosial dan ketentuan penerapan protokol kesehatan menyebabkan pembelajaran yang biasanya dilaksanakan secara tatap muka kini ditiadakan. Sebagai gantinya pendidikan dengan pembelajaran jarak jauh harus diterapkan.

Tidak hanya untuk perguruan tinggi, tetapi pendidikan tingkat dasar dan menengah pun harus menerapkan pembelajaran jarak jauh yang kini dikenal dengan istilah pembelajaran daring. Meskipun beberapa wilayah telah memulai pembelajaran secara tatap muka di sekolah, akan tetapi tidak sedikit pula yang masih menyelenggarakan program pendidikan jarak jauh. SDN 2 Nglobo merupakan salah satu lembaga pendidikan formal yang menyelenggarakan pendidikan tingkat dasar di wilayah Kabupaten Blora harus menerapkan pembelajaran daring karena berdasarkan kategori wilayah kasus penyebaran covid-19 masih relatif tinggi.

Perubahan program pendidikan secara tatap muka menjadi daring menimbulkan berbagai tantangan dan hambatan yang relatif banyak. Bukan hanya menjadi permasalahan bagi pendidik, melainkan peserta didik pun harus mampu menyesuaikan gaya belajar dan sarana prasarana yang ada. Dari sekian banyak permasalahan yang dihadapi oleh pendidik dan peserta didik, terdapat beberapa permasalahan berkaitan dengan pelaksanaan pembelajaran IPA Tema 5 Subtema 3 Keseimbangan Ekosistem pada siswa kelas V.

Dari kegiatan pembelajaran yang telah dilaksanakan diketahui bahwa siswa kurang aktif dalam kegiatan yang hanya dilakukan melalui whatsapp grup. Hal ini ditunjukkan dengan rerata nilai yang diperoleh saat evaluasi yang masih tergolong rendah. Selain itu, tingkat ketuntasan peserta didik dalam mata pelajaran IPA khususnya yang hanya mencapai $40 \%$.

$$
\text { Ada beberapa penyebab rendahnya hasil belajar IPA }
$$

Tema 5 Subtema 3 berkaitan kehidupan sosial, diantaranya : (1). Banyak siswa yang mengeluhkan kapasitas memori atau penyimpanan yang cepat penuh jika harus selalu mengirimkan hasil pekerjaan berupa foto, video, atau rekaman suara.(2) Siswa kurang disiplin dalam mengerjakan tugas yang diberikan secara tertulis karena tidak semangat untuk mengerjakan tugas yang monoton tanpa media yang menarik. (3) Keterbatasan kemampuan siswa dan sarana dalam memanfaatkan media pembelajaran daring seperti zoom, moodle, ataupun google metting.

Dari hasil identifikasi masalah yang telah disampaikan di atas, maka dapat diketahui bahwa hasil pembelajaran yang relatif rendah dikarenakan penggunaan media pembelajaran yang masih konvensional sehingga diperlukan media pembelajaran lain yang efektif, dan efisien untuk menunjang aktifitas pembelajaran secara daring.

Media adalah alat bantu apa saja yang dapat dijadikan sebagai penyalur pesan guna mencapai tujuan pengajaran (Djamarah, 2002). Google form merupakan aplikasi google bebas bayar yang fungsi utamanya untuk membuat formulir baik untuk pengumpulan informasi maupun kuis secara online. Ini salah satu alat yang mudah digunakan bahkan bagi para pemula sekalipun karena tidak menggunakan koding untuk pembuatannya. Aplikasi ini berbasis web maka setiap orang dapat memberikan tanggapan atau jawaban terhadap kuis ataupun kuisioner secara cepat dimanapun ia berada dengan menggunakan aplikasi internet komputer/ laptop ataupun Handphone. Karena itu, dengan menggunakan aplikasi ini maka seorang guru atau pegawai tidak memerlukan kertas lagi untuk 


\section{SHEs: Conference Series 3 (3) (2020) 882- 886}

mencetak kuis atau kuisionernya. Waktu yang diperlukannya juga akan semakin hemat dalam membagikan,mengumpulkan kembali dan menganalisis hasil kuis dan angketnya. Berdasarkan uraian di atas, penulis akan mencoba melakukan penelitian dengan judul Peningkatan Hasil Belajar IPA Tema 5 Menggunakan Media Google Form pada Siswa Kelas V. Tujuan penelitian ini adalah meningkatkan hasil belajar siswa pada IPA Tema 5 Subtema 3 tentang Keseimbangan Ekosistem.

\section{METODE}

Penelitian ini merupakan penelitian tindakan kelas (PTK) kolaboratif yang dilaksanakan dalam dua siklus, setiap siklus terdiri dari tahap perencanaan, pelaksanaan, observasi, dan refleksi. Subjek penelitian ini adalah peserta didik kelas V SD Negeri 2 Nglobo tahun pelajaran 2020/2021 yang berjumlah 20 siswa.

Data yang dianalisis berupa data kuantitatif yaitu hasil belajar IPA peserta didik. Teknik pengumpulan data dengan teknik observasi dan tes. Adapun instrument penilaiannya menggunakan butir - butir soal dan pengamatan rubrik penilaian. Analisa data yang digunakan dalam penelitian meliputi teknik deskriptif komparatif yakni teknik statistik dengan membandingkan skor antar siklus, mean, skor minimal, maksimal dan persentase. Hasil penelitian bahwa Penggunaan media google form dapat meningkatkan hasil belajar peserta didik pada IPA tema 5 subtema 3 tentang keseimbangan ekosistem.

HASIL DAN PEMBAHASAN

Hasil penelitian menunjukkan peningkatan hasil belajar pada IPA tema 5 Terlihat pada tabel berikut.

Tabel 1. Hasil Tes Akhir Siswa

\begin{tabular}{cccc}
\hline No & Range Nilai & $\begin{array}{c}\text { Jumlah Siswa } \\
\text { Siklus I }\end{array}$ & $\begin{array}{c}\text { Jumlah Siswa } \\
\text { Siklus II }\end{array}$ \\
\hline 1. & $81-100$ & 0 & 9 \\
2. & $61-80$ & 10 & 8 \\
3. & $41-60$ & 6 & 1 \\
4. & $21-40$ & 4 & 2 \\
5. & $0-20$ & 0 & 0 \\
\hline
\end{tabular}




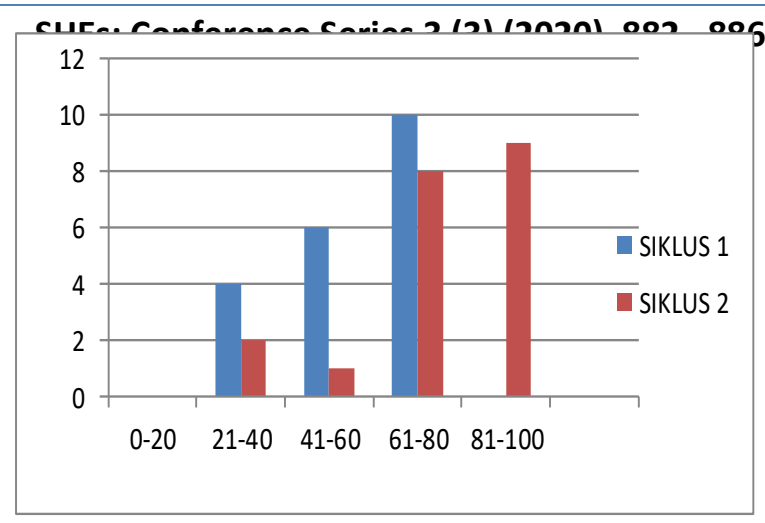

\section{Gambar 1. Hasil Tes Akhir Siswa}

Peningkatan hasil belajar IPA Tema 5 subtema 3 diukur dengan menggunakan teknik tes hasil belajar dengan soal evaluasi google form. Teknik pengumpulan data hasil belajar peserta didik diterapkan di setiap pertemuan setelah dilakukan kegiatan pembelajaran. Aspek yang diukur yaitu aspek kognitif atau pengetahuan yang terdiri dari menganalisis (C4) dan menemukan (C4) yang diukur berdasarkan hasil evaluasi setelah mengikuti pembelajaran dengan menggunakan media google form pada IPA tema 5 subtema 3 tentang keseimbangan ekosistem.

Penggunaan media google form dalam evaluasi pembelajaran IPA dapat meningkatkan hasil belajar peserta didik di kelas V SD Negeri 2 Nglobo. Pada hasil penilaian sebelumnya persentase ketuntasan belajar hanya $40 \%$. Setelah dilakukan tindakan, persentase ketuntasan belajar meningkat menjadi $50 \%$. Pada siklus II terjadi peningkatan kembali yang mencapai 85\% dengan KKM 67.

Berdasarkan tabel hasil belajar peserta didik terhadap penggunaan media google form dapat dilihat bahwasanya peserta didik sangat tertarik untuk menggunakan media google form dalam pembelajarannya. (Luqman et al., 2017) menyatakan bahwa pembelajaran yang menyenangkan, menarik minat dan tidak membosankan peserta didik, salah satu awal agar pembelajaran menjadi bermakna yang pada akhirnya dapat meningkatkan hasil belajar peserta didik.

\section{SIMPULAN}

Penggunaan media google form dalam evaluasi pembelajaran sangat memotivasi siswa dalam belajar. Media google form dapat menarik minat dan keaktifan siswa dalam kegiatan pembelajaran. Hal ini sangat berpengaruh terhadap peningkatan hasil belajar siswa yang dengan ketuntasan hasil belajar peserta didik pada siklus I sebesar 50\%, meningkat menjadi $85 \%$ pada siklus II.

Berdasarkan hasil penelitian tindakan kelas tersebut, guru dapat melibatkan siswa dalam pemanfaatan kemajuan teknologi dengan bantuan media google form agar siswa lebih menguasai materi pembelajaran, sehingga hasil belajarnya meningkat. Sekolah hendaknya memotivasi guru untuk terus berusaha memanfaatkan teknologi dalam kegiatan pembelajaran yang berdampak pada peningkatan hasil belajar siswa.

\section{DAFTAR PUSTAKA}

Arikunto, Suharsimi. 2010. Prosedur Penelitian Suatu Pendekatan Praktik. Jakarta: Rineka Cipta. 
SHEs: Conference Series 3 (3) (2020) 882- 886

Arsyad, Azhar. 2009. Media Pembelajaran. Jakarta : PT Raja GrafindoPersada. Asyhar, Rayandra. 2012. Kreatif Mengembangkan Media Pembelajaran. Jakarta: Referensi Jakarta.

https://rumushitung.com/2018/08/29/apa-sih-yang-dimaksud-dengan-keseimbanganekosistem-itu/

http://edel.staff.unja.ac.id/blog/artikel/Pengertian-Media-Pembelajaran.html https://koreshinfo.blogspot.com/2016/02/pengertian-ptk-penelitian-tindakan.html https://www.zonareferensi.com/pengertianpembelajaran/content/uploads/2020/03/artikel_googleform_wibi_032020_4.p df 